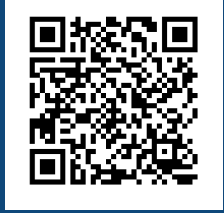

Keywords:

Wooden structures

Fastener

Stiffness

Tropical wood

Tropical species

Historic:

Received 30/04/2019

Accepted 22/05/2019

+Correspondence: rmoya@itcr.ac.cr
Monzerrath Rivera-Tenorio'a, Roger Moya ${ }^{1+}$

\section{STRESS, DISPLACEMENT JOINTS OF Gmelina arborea AND Tectona grandis WOOD WITH METAL PLATES, SCREWS AND NAILS FOR USE IN TIMBER TRUSS CONNECTIONS}

RIVERA-TENORIO, M.; MOYA, R. Stress, displacement joints of Gmelina arborea and Tectona grandis wood with metal plates, screws and nails for use in timber truss connections. CERNE, v. 25, n. 2, p. I72-183, 2019.

\section{HIGHLIGHTS}

The joints structural behavior made with melina and teak wood was studied.

Angles of $0^{\circ}$ and $90^{\circ}$; and metal plates, screws and nails connectors were used.

The highest load values were obtained in metal plates in the two angles.

The test showed that the prediction was low, the bias was $3 \%$.

\section{ABSTRACT}

In countries like Costa Rica, there is an interest in developing wooden trusses in a versatile and light way. However, there is a key aspect in the behavior of truss connections in this product. Therefore, the present study determines the structural behavior of the truss connections and the displacement, the resistance, the stiffness values and the failure mode of truss connections made with Gmelina arborea and Tectona grandis timber for angles of $0^{\circ}$ and $90^{\circ}$; and three types of truss connectors (metal plates, screws and nails), subject to tension and compression loads. The results showed that metal plates show the highest load values with respect to the nails and screws in both species. Likewise, in the design and critical displacement stress, metal plates surpass the nails and screws in both species; and in the two angles. From these stress values, we proposed a model for the prediction of the stiffness for the truss connections of the intermediate angles $\left(30^{\circ}, 45^{\circ}\right.$ and $\left.60^{\circ}\right)$ and the test showed that the prediction was low, the bias was $3 \%$. 


\section{INTRODUCTION}

Wood is considered an excellent construction material, not only for its technical qualities but for its environmental qualities (Hei et al., 2016). It is highly resistant in relation to its weight, is easy to install, to join with nails, bolts and adhesives, imparts its warmth and aesthetic beauty, very important qualities in civil structures (Songet al., 2015). Most wooden structures are generally light constructions, known as framing, which are characterized by being made of low-dimensional wood with the use of numerous connectors, and which together contribute to resist seismic forces (CWC, 20I7a).

For this reason, there is an increasing interest in having more information about the behavior of wood and the elements that are added to it, as structural element in development countries. This leads, to investigate and analyze, each of the main structural elements used in the design and construction of wooden buildings (Zhang et al., 20I5), where the truss is a versatile and lightweight structural option (Green and Karsh, 2012). The construction of structural systems with wood, such as trusses, is increasing all over the world, thanks to improvements in materials, design and manufacturing technologies (CWC, 20I7b). As in any structural design material, from time to time they are subject to changes and improvements, hence the admissible stress and the way in which these stress are applied must be analyzed (Barbari et al., 20l4).

To guarantee the optimal behavior of a truss before different events, it is necessary to study the truss connections between the elements that compose it, since these constitute the weak point of wooden structures (Ellegaard, 2007). Truss connections are a key point in the materialization of this type of structures, since the knots or truss connections must be able to transmit the stress between elements without compromising the stiffness and geometry of the system (Zhang et al., 20l8).

The construction of trusses in the past used steel connectors or mechanical fastening systems using nails, bolts, and others. (Fueyo et al., 2009). However, this type of connectors has several drawbacks such as: the need for a greater number of elements for a single truss connections, or that when supporting loads, the nails or bolts can produce checks in the wood, etc. (SBCA and TPI, 2013). This problem led to the introduction of connectors or metal plates, which have led to a new philosophy in truss systems (SBCA and TPI, 20I3). According to Rammer (2016), with the metallic plates it is possible to obtain a greater resistance in the truss and solve the problems that occur when truss connections used nails and screws.
On the other hand, in developing countries, connectors such as nails and screws are still used, mainly due to their low cost (Prevatt et al., 2014, Moya and Tenorio, 2017). Sawata et al. (2013) mentions that in the aspects of resistance of connectors in wooden joints of different types: metal plates, screws and nails, these are hardly known in the structures built with tropical species. Moya and Tenorio (2017) in a recent study present the determination of the values of resistance, stiffness and failure mode of truss connections with nails and screws using the evaluation methods of Gebremedhin et al. (1992) and McCarthy and Wolfe (1987). However, these methods have been developed for metal plate type connectors.

Moreover, timber of Gmelina arborea and Tectona grandis from forest plantations are the most used in the Costa Rican market and also in other countries with tropical climate (Serrano and Moya, 20II; Dvorak, 2004; Moya et al., 20I4). Regarding G. arborea species, there have been several advances in its use, since it covers a growing lack of raw material for the timber industry in Costa Rica, where its uses range from the furniture, construction, packaging, plywood, pencils, and others. (Serrano and Moya, 20II). Meanwhile, timber of $T$. grandis enjoys an excellent reputation due to its properties: strong, light, durable, dimensional stability and hardness; with a great variety of traditional and current uses; among them, quality furniture, structural elements, carpentry, veneers, floors and marine uses (Keogh, 20I3).

Although the fundaments, theory and applications of timber truss connection is widely known in countries with tradition in the structural use of timber (CWC, $2017 b$ ). In this sense, special reference should be made to the work carried out by Johasen (1949) on the behavior of truss connectors in timber. This study has served to develop all the theoretical aspects in plate and bolt. But, its application in developing countries is very limited (Prevatt et al., 2014, Moya and Tenorio, 2017) due to little knowledge of these principles. Likewise, its application in species of great interest in commercial plantations, such as G. arborea or T. grandis, and international tropical timber markets (Keogh, 20I3; Dvorak, 2004) is also limited. Then it is establishment of the structural behavior of unions will contribute more knowledge to the use of these species in uses that increase the added value of the wood and especially the structural use of the species.

Specifically, the information available on the use of these two plantations timber, knowledge of the structural properties of these timbers are still lacking in framing- 
type construction processes such as prefabricated trusses (Tenorio et al., 2017) and especially in the joints that are used in the trusses (Moya and Tenorio, 2017). Therefore, the present work seeks to determine the structural behavior of the truss connection and displacement in relation to the applied forces, as well as the resistance, the stiffness values and the failure mode of the truss connections made with $G$. arborea and T. grandis for angles of $0^{\circ}$ and $90^{\circ}$. And verify the difference between three types of connectors (metal plates, screws and nails), subject to tension and compression loads. From this, a model for the prediction of the stiffness for the truss connections of the intermediate angles $\left(30^{\circ}, 45^{\circ}\right.$ and $\left.60^{\circ}\right)$ is proposed.

\section{MATERIAL AND METHODS}

\section{Raw materials employed}

Timber used came from trees of Gmelina arborea and Tectona grandis from forest plantations in Costa Rica. The first species was selected for its high rate of reforestation in this country (INEC, 20I4) and because G. melina timber is employed for many uses, for example the potential for structural use (Vallejos et al., 2015; Moya and Tenorio, 2017; Moya et al., 2013; Tenorio et al., 2017). As for T. grandis, it is selected because it has a dimensional stability with admissible design stress comparable with the group of semi-hardwood species (Moya and González, 20I4), which makes T. grandis a versatile wood for a wide variety of uses such as structural elements (Keogh, 20I3). Wood from G. arborea was obtained from the sawmill Maderas S.Q. 2008 (Pérez Zeledón, San José, Costa Rica) and the wood from $T$. grandis comes from the plantations of Novel Teak located in Liberia, Guanacaste, Costa Rica.

\section{Truss connection design and manufacturing}

Timber used to manufacture of truss connections of both species had a dimension of $2.2 \mathrm{~cm}$ thick and 7.2 $\mathrm{cm}$ wide, in air dry state (approximately 14\%) and without brushing. Truss connections were designed using three types of fasteners and two types of angles: $0^{\circ}$ and $90^{\circ}$ and joined by: metal plates, screws and nails (Figure I). Metal plates used as truss connections were $6.5 \mathrm{~cm}$ wide, 10.0 $\mathrm{cm}$ long and tooth thickness less than $7.9 \mathrm{~cm}$. Each truss connection used two plates, one on each side of the truss connection. These plates were installed using a manual press built for this purpose with a pressure of $46.50 \mathrm{~kg} \cdot \mathrm{cm}^{-2}$. Screws used for truss connections were of the flat-head Phillips type for wood, $5.0 \mathrm{~cm}$ long $\times 0.43 \mathrm{~cm}$ in diameter. While nails used were $5.1 \mathrm{~cm}$ long $\times 0.28 \mathrm{~cm}$ in diameter. In the last two fasteners, ten screws and/or ten nails were used, placing five in each piece of the sample. Distribution of nails and screws was the same for both species. In total, 240 truss connections were made per species ( 2 angles $\times 3$ type of fastener $\times 2$ species $\times 20$ repetitions).

\section{Truss connection test and calculation of stress}

The 240 truss connections were tested in two types of load: compression (I20 truss connections) and tension (I20 truss connections). These tests were performed using a test frame device (Figure 2), specifically designed to dispose and test the different truss connections (Tenorio et al. 20l7). This device was connected to a test machine brand Tinus Olsen with a capacity of 60 Ton. The test frame device was placed in such a way that the load was applied vertically on the sample to be tested. In the compression test, no support was needed to apply the load (Figure 2a), while in the tension test a mobile support was placed on the upper part of the truss connection (Figure 2b). Each truss connection was supported to the test frame using screws, which supported the load applied at a distance of $33 \mathrm{~cm}$ approximately from the center of the truss connection, totaling a support distance of $66 \mathrm{~cm}$ (Figure 2).

In both tests (compression and tension), the load was applied in order that the displacement of the truss connection followed the plane of the load, at a speed of

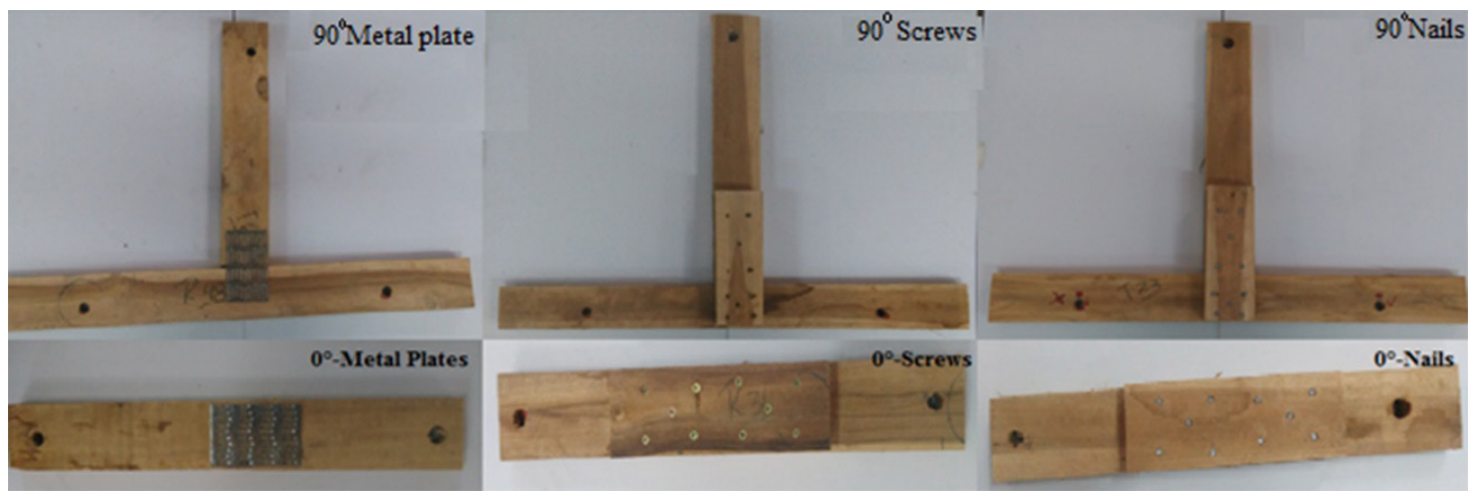

FIGURE I Orientation of truss connections and distribution of metal plates, nails and screws. 

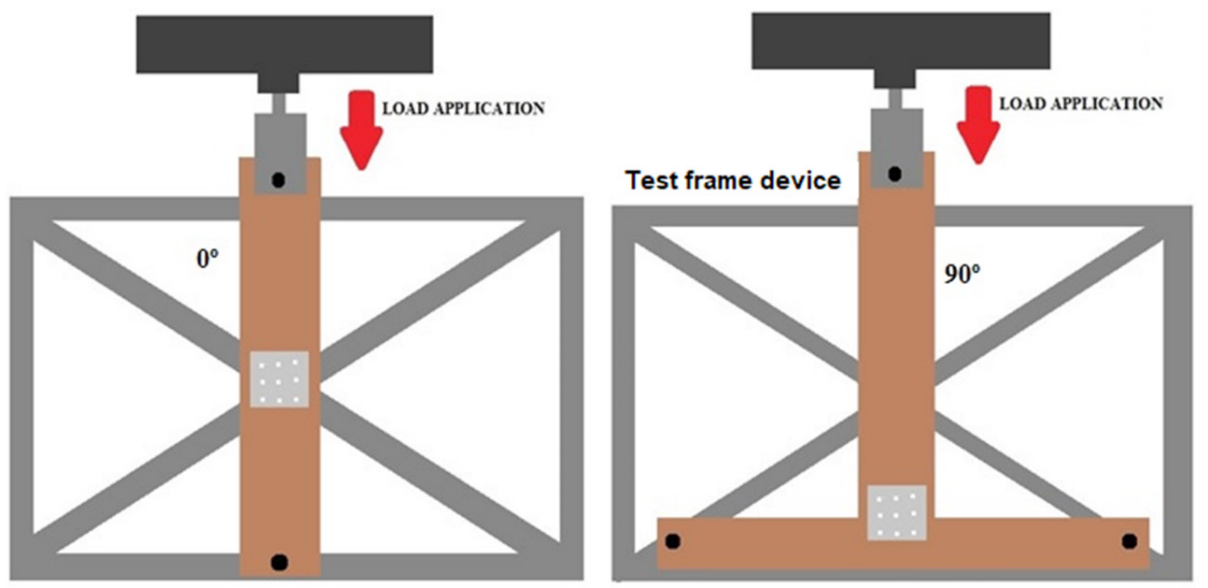

FIGURE 2 Test frame device employed for compression testing truss connection (a) and applying loads during tension tests (b).

$0.2 \mathrm{~cm} \cdot \mathrm{min}^{-1}$. The tests in compression and tension were performed using test conditions used by Gebremedhin et al. (1992) for similar truss connection fixed with dented metal plates. Each trial lasted between 9 and $20 \mathrm{~min}$. This lapse was consistent with ASTM DI76I-06, which states that failure should occur between 5 and 20 min (ASTM 20I2).

During the tests, values for loads and displacements for each truss connection were recorded. Then, data were exported to the Microsoft Excel software, where a graph of load vs. joint displacement for each truss connection subjected to load. On the curve load vs. displacement, the following parameters were determined: maximum force in compression (Fmax-compr) or maximum force in tension (Fmax-tension), maximum displacement, displacement in the proportional limit and load to a displacement of $0.381 \mathrm{~cm}$.

From these mentioned values, we followed with the calculation of the design stress in tension and compression and the critical displacement stress, also in tension and compression, according to the procedure described in Gebremedhin et al. (1992). The design stress was calculated using equation I. While the critical displacement stress was calculated using equation 2 .

Maximuimstress $(M p a)=\frac{\left(\frac{\left(\frac{(\text { Maximumload }(\mathrm{k} g))}{(\text { Maximumdisplacement }(\mathrm{cm}))}\right)}{3}\right)}{10.197}$

Criticaldisplacementstress $($ Mpa $)=\frac{\left(\frac{(\text { Loadof } 0.38 \mathrm{~cm}(\mathrm{~kg}))}{0.381}\right)}{10.197}$

After obtaining the previous values, we continued with the calculation of stiffness for the intermediate angles $\left(30^{\circ}, 45^{\circ}\right.$ and $\left.60^{\circ}\right)$, according to the formula described in equation 3. This equation is extensively detailed by Gebremedhin et al. (1992). Where: $k_{\theta}=$ stiffness expected for an intermediate angle between $0^{\circ}$ and $90^{\circ}, \theta=$ angle between the applied load and grain orientation, $k / /$ and $k_{\theta}=$ critical displacement stress for angles $0^{\circ}$ and $90^{\circ}$, respectively, $n=$ exponential factor,
In this case, exponential factors of $1.0,1.25,1.5$, 1.75 and 2.0 were used, since these values are used to calculate stiffness in wood, at intermediate angles, for stress and compression testing.

Then, values of $k_{\theta}$ were established for each intermediate angle $\left(30^{\circ}, 45^{\circ}\right.$ and $\left.60^{\circ}\right)$ from the displacement stress values obtained in the compression and tension tests for each species, for each factor ( $n$ ) (I, I.25, I.5, I.75 and 2). With this, dispersion graphs were developed with the distribution of $k_{\theta}$ values with each angle and then, to develop the best fit line that will corresponds to the $n$ in equation 3. This adjustment was performed for each truss connection type and species and thus obtain the predictive model for intermediate angles, detailed in equation 3. Finally, the predictive model was to evaluate. Five samples for each of the following angles, $30^{\circ}, 45^{\circ}$ and $60^{\circ}$ were fabricated in $G$. arborea wood truss connection with nail and they were tested in compression force. The stiffness values obtained for these angles were plotted together with the curve of the predictive model and so it was evaluated the capacity of prediction. Likewise, the bias of the data obtained was calculated.

$$
\mathrm{k}_{\theta}=\mathrm{k}_{/ /} \cdot \mathrm{k}_{\perp} /\left(\mathrm{k}_{/ /} \sin ^{\mathrm{n}} \theta \cdot \mathrm{k}_{\perp} \cos ^{\mathrm{n}} \theta\right)
$$

\section{Physical properties of timber}

Timber density and moisture content (MC) were determined for each sample (all truss connection at angles of $0^{\circ}$ and $90^{\circ}$, for each type of fastener: metal plate, nails and screws). Each truss connection was weighed before the test and the dimensions of each truss connection piece were measured to calculate the volume and then, calculate timber density $\left(\mathrm{kg} \cdot \mathrm{m}^{-3}\right)$. Percentage of $M C$ was measured for each sample with a hydrometer DELMHORST brand, each piece was measured in three 
parts: one at each end at $3 \mathrm{~cm}$ from the edge and at the center (For samples at an angle of $90^{\circ}$, it was measured in the bottom piece of each sample) and then averaged.

\section{Statistical Analysis}

Adescriptiveanalysis was developed, in which medians, standard deviations, coefficients of variation, maximum and minimum values were determined for the variables involved: moisture content, density, loads and maximum displacements, loads and displacements in the proportional limit, design stress; and critical displacement stress.

Additionally, normal distribution and homogeneity of variances for the data was verified. Then an analysis of variance was applied to confirm the existence of significant differences among the averages of variables $(P<0.05)$ for each species (G. arborea and T. grandis), considering the type of fastener used (metal plates, nails and screws) and the truss connection angle $\left(0^{\circ}\right.$ and $\left.90^{\circ}\right)$. Finally, a Tukey test was established to determine statistical differences between the medians of the three types of fasteners.

\section{RESULTS}

\section{Physical properties of timber}

In the physical properties of timber evaluated, a moisture content of approximately $1 \mathrm{I} .5 \%$ was obtained for timber samples at angle of $0^{\circ}$ and angle of $90^{\circ}$ for $G$. arborea and, of $10.4 \%$ for $T$. grandis with statistically equal values for both angles evaluated for both species. In the case of density, significant differences were evidenced between timber at angles of $0^{\circ}$ and $90^{\circ}$, where density at $0^{\circ}$ was greater, this for both species (Table I).

TABLE I Physical properties of Gmelina arborea and Tectona grandis lumbers used to manufacture truss connection.

\begin{tabular}{ccccc}
\hline \multirow{2}{*}{ Angle } & \multicolumn{2}{c}{ Gmelina arborea } & \multicolumn{2}{c}{ Tectona grandis } \\
\cline { 2 - 5 } & Moisture & Density & Moisture & Density \\
& content $(\%)$ & $\left(\mathrm{kg} \cdot \mathrm{m}^{-3}\right)$ & content $(\%)$ & $\left(\mathrm{kg} \cdot \mathrm{m}^{-3}\right)$ \\
\hline \multirow{2}{*}{$0^{\circ}$} & II.68A & $413.62 \mathrm{~A}$ & $10.57 \mathrm{~A}$ & $527.10 \mathrm{~A}$ \\
& $(20.06)$ & $(34.85)$ & $(19.64)$ & $(13.68)$ \\
\hline \multirow{2}{*}{$90^{\circ}$} & $11.30 \mathrm{~A}$ & $444.26 \mathrm{~A}$ & $10.29 \mathrm{~A}$ & $541.20 \mathrm{~A}$ \\
& $(27.90)$ & $(17.87)$ & $(18.14)$ & $(8.28)$ \\
\hline
\end{tabular}

Note: Values in parentheses correspond to the coefficient of variation of each properties. Letters in averages indicate significant statistical differences between angles at $95 \%$.

\section{Types of failure present in truss connection}

Failures that were presented in the tension and compression tests, for angles of $0^{\circ}$ and $90^{\circ}$ in both species were different for each type of fastener: for truss connection with metal plates, in the largest number of tests, a failure in the truss connection was observed due to timber, in the lateral parts of the piece specifically; and not in the fastener. However, in very few cases there was a lateral lift on the edges of the metal plate (Figure 3a). In truss connection fastened with screws, a detachment of the screws was observed, causing therefore total separation of the pieces in the truss connection (Figure 3b). As for truss connections with nails, the lateral separation of the pieces in the truss connection happened, namely, nails of the edges of the truss connections are detached, leaving the truss connection connected by the center nails (Figure $3 c$ ).

Maximum load and maximum displacement values in tension and compression

Maximum force in compression (Fmax-comp) of joints constructed with dented metal plates and $G$. arborea timber for truss connection at angles of $0^{\circ}$ and $90^{\circ}$ are statistically greater than when nails and screws are used in truss connection (Figure 4a). But for the same species, with these two types of fasteners (nails and screws), in truss connection with $0^{\circ}$ angle, the Fmaxcomp are statistically equal between them. While in truss connection at a $90^{\circ}$ angle with screws have values of Fmax-comp statistically lower than the Fmax-comp in truss connection with metal plates, but this last one does not present difference in the Fmax-comp in relation to truss connection with nails (Figure $4 \mathrm{a}$ ).

In truss connection constructed with $T$. grandis timber, the Fmax-comp in truss connections of $0^{\circ}$ angle with metal plate fasteners is statistically greater than truss connections with nails and screws. In truss connections with a $90^{\circ}$ angle, the fastener with Fmaxcomp were presented in truss connections with nails; and it is significantly different from metal plates and screws, which did not present Fmax-comp difference between the two types of fasteners (Figure 4b).

In the tension test, maximum loads (Fmax-tension) for truss connections at $0^{\circ}$ angle with $G$. arborea timber, the Fmax-tension is greater for screw truss connection, but is significantly equal to metal plates; and both truss connections greater than truss connections with nails (Figure 4a). As for $T$. grandis at $0^{\circ}$ angle, the three fasteners do not show significant differences (Figure 4b). Meanwhile, truss connections at $90^{\circ}$ with metal plate in $G$. arborea were statistically higher. However, for truss connections of this species with nails and screws, the value of Fmax-tension were statistically equal (Figure 4a). For T. grandis the three fasteners used in the $90^{\circ}$ truss connections are statistically different, the analysis found that truss connections with plates have less Fmax-tension than truss connections with nails, but higher in Fmax-tension than truss connections with screws (Figure 4b). 


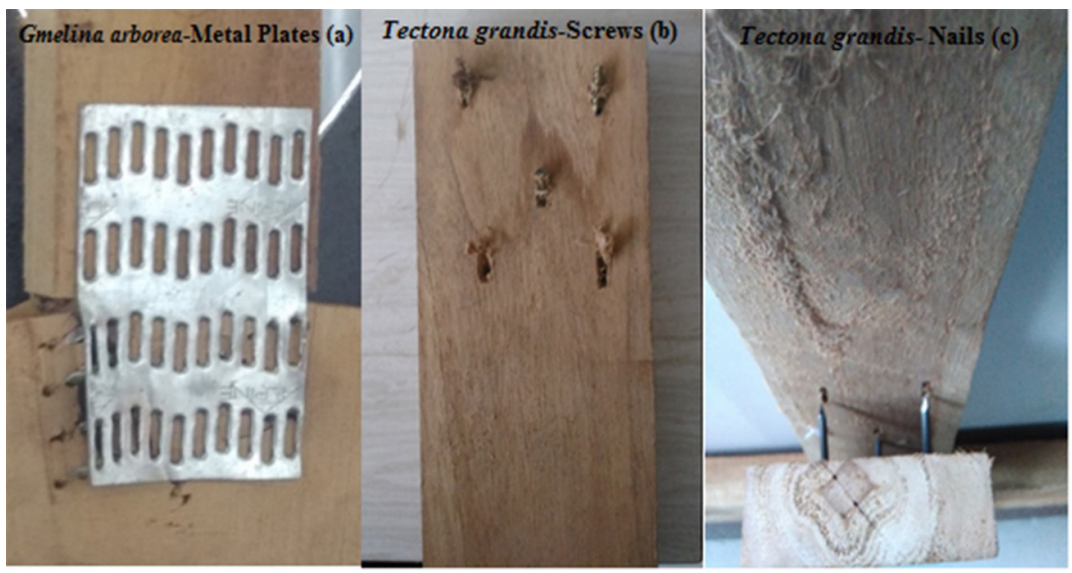

FIGURE 3 Types of fastener failure of metal plates (a), screws (b) and nails (c) in Gmelina arborea and Tectona grandis, tested in compression and tension.
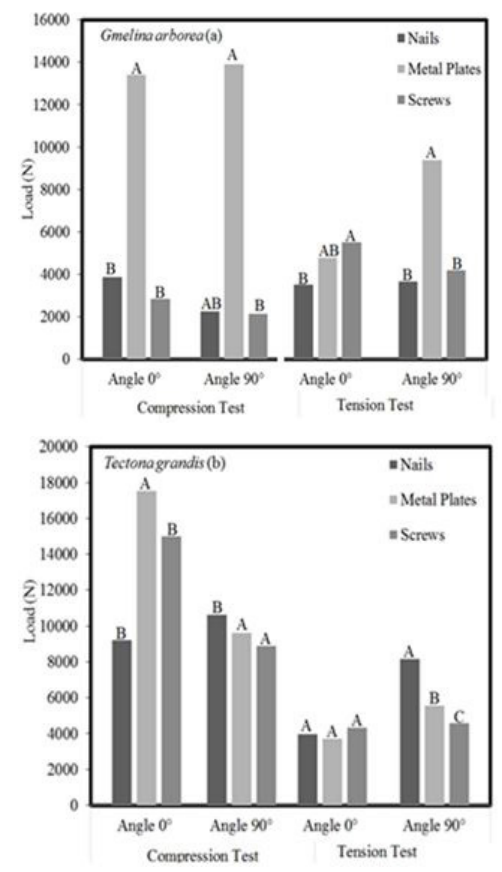

FIGURE 4 Maximum loads of truss connections constructed with Gmelina arborea (a) and Tectona grandis (b) lumbers using different angles and fasteners, tested in compression and tension. Note: Letters A-B-C, indicate significant statistical differences between fasteners at $95 \%$.

In the compression test, in truss connections at angles of $0^{\circ}$ and $90^{\circ}$ with $G$. arborea timber, displacement was greater for truss connections with screws and statistically greater than truss connections with metal plates and nails. On the contrary, for $0^{\circ}$ and $90^{\circ}$ angles with this same species, the greatest displacement occurs with nails and is statistically different from truss connections with metal plates and screws that share statistical similarity with each other (Figure 5a). For truss connections with $T$. grandis timber at $0^{\circ}$ angle, the three types of truss connections do not show significant differences in the displacement of the truss connection. In the case of $90^{\circ}$ angle, truss connections with metal plate and screw have a higher displacement value, and the displacement is statistically greater than truss connections with nails (Figure 5b). As for truss connections of T. grandis at $0^{\circ}$ in tension, the highest values of displacement occur for truss connections with nails and screws and in turn are significantly different from truss connections with metal plates (Figure $5 \mathrm{~b}$ ). In the $90^{\circ}$ angle, the greatest displacement in tension occurs in truss connections with nails and in the case of truss connections with metal plates and screws do not differ with the nails (Figure 5a-b).


FIGURE 5 Maximum displacement in truss connections made using different angles and fasteners from Gmelina arborea and Tectona grandis, tested in compression ( $a-b)$ and tension (a-b). Note: Letters A-B, indicate significant statistical differences between fasteners at $95 \%$. 


\section{Load behavior vs. displacement of truss connections}

Graphical behavior of the displacement with the load for truss connections with $G$. arborea in the compression and tension tests, confirms that truss connections with metal plates in both angles of $0^{\circ}$ and $90^{\circ}$ have the greatest resistance, whereas truss connections with the lowest load value are those truss connections with screws at $90^{\circ}$ angle for both tests. For compression, the lowest value is presented for truss connections with screws at $0^{\circ}$ angle and in tension, the lowest value is for truss connections with nails for the angle of $90^{\circ}$ (Figure 6a-c). In case of the displacement curve of $T$. grandis truss connections for the compression test, the highest load values are found in truss connections with nails at $90^{\circ}$ angles and the lowest load value is for screw truss connections in the $90^{\circ}$ angle, but with similar displacements to those that occur in truss connections with nails and screws (Figure 5b). In the tension test, the highest values in load and displacement, again appear in truss connections with metal plates at $90^{\circ}$ angles. While the rest of the truss connections have a similar displacement-load ratio, except for truss connections with nails at $90^{\circ}$ angles (Figure 6d).

The results presented previously shown that truss connection with metal plates, nails and screws, suggest that they present a different behavior in relation to timber connections established by Johasen (1949). The mainly the difference was found load behavior vs. displacement of truss connection curve. In this study with timber truss connections, a little plastic region is presented, however the models presented for the Johansen timber connections

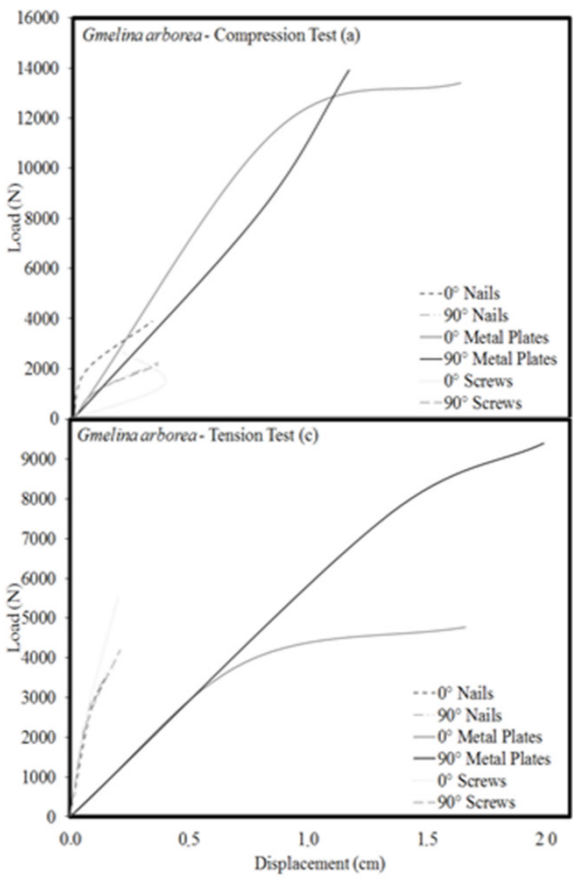

(1949) present more plastic regions. The load-displacement curve suggests that the type of test carried out in the present study results in more rigid unions than the type of timber connections presented by Johasen (1949). In addition, another difference is that in the present study the truss connections used are common in timber truss connections, whereas the study by Johasen (1949) are timber truss connections of a different configuration from the present study. Then the results presented in this study, although they can be found for wood species of temperate climate in countries with traditional use in wood, is the first time that the results are presented for wood coming from tropical climates and growing in forest plantations.

\section{Design values}

Design stress and the critical displacement stress at $0.38 \mathrm{I} \mathrm{cm}$ that were obtained in the compression and tension tests, confirms again that the highest values are obtained for truss connections with metal plates in both angles evaluated. On the other hand, the lowest values in design stress and critical displacement stress are found in the compression and tension test, for both species at $90^{\circ}$ angles with screws. At $0^{\circ}$ angles, the lowest values for both species were found in truss connections with nails for the tension test in both stresses. For the compression test, the lowest values in design stress were found in truss connections with nails for both species, while for the critical displacement stress, the lowest values are found in truss connections with screws (Table 2).

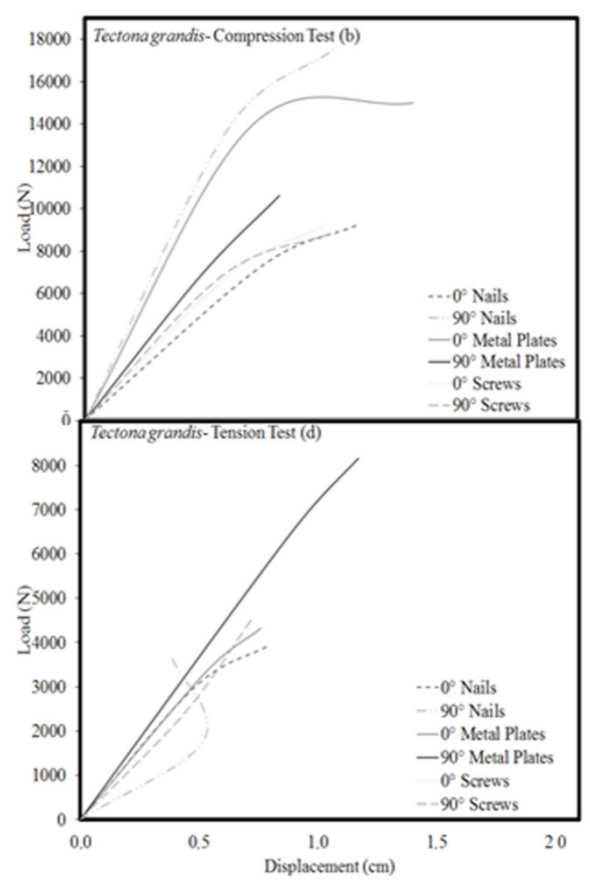

FIGURE 6 Load vs. displacement curves of truss connections made using various angles and fasteners in lumber from Gmelina arborea and Tectona grandis, tested in compression ( $a-b)$ and tension (c-d). 
TABLE 2 Design stress in truss joints for different angles and fasteners from Gmelina.arborea and Tectona grandis lumbers, tested in compression and tension.

\begin{tabular}{|c|c|c|c|c|c|c|}
\hline \multirow[b]{2}{*}{ Angle } & \multirow[b]{2}{*}{ Test } & \multirow[b]{2}{*}{ Fastener } & \multicolumn{2}{|c|}{ Gmelina arborea } & \multicolumn{2}{|c|}{ Tectona grandis } \\
\hline & & & $\begin{array}{l}\text { Design } \\
\text { stress } \\
(\mathrm{MPa})\end{array}$ & $\begin{array}{c}\text { Critical } \\
\text { displacement } \\
\text { stress } \\
(\mathrm{MPa})\end{array}$ & $\begin{array}{l}\text { Design } \\
\text { stress } \\
(\mathrm{MPa})\end{array}$ & $\begin{array}{c}\text { Critical } \\
\text { displacement } \\
\text { stress } \\
(\mathrm{MPa})\end{array}$ \\
\hline \multirow{12}{*}{$0^{\circ}$} & \multirow{6}{*}{ Compression } & \multirow{2}{*}{ Metal plates } & $10.33 \mathrm{~A}$ & $18.90 \mathrm{~A}$ & 5.07A & $22.28 \mathrm{~A}$ \\
\hline & & & Screws & $(44.15)$ & $(73.03)$ & $(36.74)$ \\
\hline & & \multirow{2}{*}{ Screws } & $5.79 \mathrm{~B}$ & $4.12 \mathrm{~B}$ & $2.86 \mathrm{~A}$ & $3.90 \mathrm{~B}$ \\
\hline & & & $(13.34)$ & $(23.17)$ & $(22.91)$ & $(28.48)$ \\
\hline & & \multirow{2}{*}{ Nails } & $4.29 \mathrm{C}$ & $4.77 \mathrm{~B}$ & $2.76 \mathrm{~A}$ & $15.02 \mathrm{C}$ \\
\hline & & & $(18.48)$ & $(17.09)$ & $(32.30)$ & $(30.00)$ \\
\hline & \multirow{6}{*}{ Tension } & \multirow{2}{*}{ Metal plates } & $15.4 I \mathrm{~A}$ & $7.47 \mathrm{~A}$ & $7.05 \mathrm{~A}$ & $4,82 \mathrm{~A}$ \\
\hline & & & $(78.11)$ & (35.43) & $(48.02)$ & $(84.73)$ \\
\hline & & \multirow{2}{*}{ Screws } & $9.62 \mathrm{~B}$ & $4.15 \mathrm{~B}$ & $3.89 \mathrm{~B}$ & $3.26 \mathrm{~A}$ \\
\hline & & & $(10.27)$ & $(24.69)$ & $(77.03)$ & $(183.27)$ \\
\hline & & \multirow{2}{*}{ Nails } & $8.12 B$ & $3.39 \mathrm{~B}$ & $3.27 \mathrm{~B}$ & $2.06 \mathrm{~A}$ \\
\hline & & & $(21.55)$ & $(13.95)$ & $(56.51)$ & $(179.04)$ \\
\hline \multirow{12}{*}{$90^{\circ}$} & \multirow{6}{*}{ Compression } & \multirow[b]{2}{*}{ Metal plates } & $4.22 \mathrm{~A}$ & $12.06 \mathrm{~A}$ & $15.12 \mathrm{~A}$ & $15.21 \mathrm{~A}$ \\
\hline & & & $(24.63)$ & $(21.30)$ & $(26.20)$ & $(32.39)$ \\
\hline & & \multirow{2}{*}{ Screws } & $2.08 \mathrm{~B}$ & $\mathrm{I} .70 \mathrm{~B}$ & $9.73 \mathrm{~B}$ & $12.80 \mathrm{~A}$ \\
\hline & & & $(23.89)$ & $(11.20)$ & $(26.69)$ & $(29.91)$ \\
\hline & & \multirow{2}{*}{ Nails } & $2.39 \mathrm{~B}$ & $1.80 \mathrm{~B}$ & $11.45 \mathrm{AB}$ & $22.34 \mathrm{~A}$ \\
\hline & & & $(32.4 I)$ & $(25.01)$ & $(102.08)$ & (95.54) \\
\hline & \multirow{6}{*}{ Tension } & \multirow{2}{*}{ Metal plates } & $18.68 \mathrm{~A}$ & $3.52 \mathrm{~A}$ & $8.34 \mathrm{~A}$ & $5.50 \mathrm{~A}$ \\
\hline & & & $(37.03)$ & $(101.15)$ & $(17.26)$ & $(50.90)$ \\
\hline & & \multirow{2}{*}{ Screws } & $6.40 \mathrm{~B}$ & $3.13 \mathrm{~A}$ & $3.99 \mathrm{~B}$ & $1.97 \mathrm{~B}$ \\
\hline & & & $(14.13)$ & $(12.11)$ & $(74.60)$ & (93.09) \\
\hline & & \multirow[b]{2}{*}{ Nails } & $8.40 \mathrm{C}$ & $3.74 \mathrm{~A}$ & $4,17 \mathrm{~B}$ & $2.99 \mathrm{AB}$ \\
\hline & & & $(25.11)$ & $(27.59)$ & $(54.62)$ & $(95.70)$ \\
\hline
\end{tabular}

Note: Values in parentheses correspond to the coefficient of variation of each properties. Letters in averages indicate significant statistical differences between fasteners by test at $95 \%$.

Prediction of stiffness for intermediate orientations

The expected stiffness values for angles of $30^{\circ}$, $45^{\circ}$ and $60^{\circ}$ were predicted based on equation 3 , and the exponential values of $n$ with a range of 1.0 to 2.0 are shown in table 3 for the compression and tension tests, with fasteners of metal plates, nails and screws. Stiffness prediction shows that the highest values are found for angles of $30^{\circ}$, regardless of the species, the test and the type of fastener; and it decreases as the angle increases.

The exponential values $(\mathrm{n})$, to predict stiffness for the different angles in both species varied from I to 1.75 from the best $R^{2}$ with a higher fit for both types of timber and type of fasteners are shown in table 4 . It is observed that for truss connections with timber of $G$. arborea in the compression test, the exponential value $(\mathrm{n})$ is 1.5 in compression and tension, not so in truss connections of nails and screws that are different in compression and tension and different from the values of $\mathrm{n}$ obtained for truss connections with nails and screws (Table 4). Whereas for truss connections with $T$. grandis in the compression test, the value of $\mathrm{n}$ is equal in plates and nails, and both are different from the screws, while in the tension tests, the three types of fasteners maintain the value of $\mathrm{n}$ in $\mathrm{I} .5$ (Table 4).

\section{DISCUSSION}

\section{Characteristics of timber employed}

MC was no significant differences between angles by species (Table I), a situation that indicates that humidity
TABLE 3 Stress prediction for intermediate angles of truss connections made using various angles and fasteners from Gmelina arborea and Tectona grandis lumbers, tested in compression and tension.

\begin{tabular}{|c|c|c|c|c|c|c|c|c|}
\hline \multirow{2}{*}{ Test } & \multirow{2}{*}{ Fastener } & \multirow{2}{*}{ Angle } & \multicolumn{3}{|c|}{ Gmelina arborea } & \multicolumn{3}{|c|}{ Tectona grandis } \\
\hline & & & 1.0 & 1.5 & 2.0 & 1.0 & 1.5 & 2.0 \\
\hline \multirow{14}{*}{ Compression } & \multirow{5}{*}{$\begin{array}{l}\text { Metal } \\
\text { Plates }\end{array}$} & $0^{\circ}$ & - & - & - & - & - & - \\
\hline & & $30^{\circ}$ & 11.46 & 13.90 & 16.55 & 13.93 & 16.82 & 19.95 \\
\hline & & $45^{\circ}$ & 10.41 & 12.38 & 14.72 & 12.78 & 15.19 & 18.07 \\
\hline & & $60^{\circ}$ & 10.18 & 11.69 & 13.26 & 12.59 & $|4.5|$ & 16.51 \\
\hline & & $90^{\circ}$ & - & - & - & - & - & - \\
\hline & \multirow{5}{*}{ Screws } & $0^{\circ}$ & - & - & - & - & - & - \\
\hline & & $30^{\circ}$ & 1.98 & 2.48 & 3.04 & 3.83 & 4.27 & 4.72 \\
\hline & & $45^{\circ}$ & 1.70 & 2.02 & 2.41 & 4.23 & 5.03 & 5.98 \\
\hline & & $60^{\circ}$ & 1.59 & 1.79 & 1.99 & 5.10 & 6.51 & 8.15 \\
\hline & & $90^{\circ}$ & - & - & - & - & - & - \\
\hline & \multirow{5}{*}{ Nails } & $0^{\circ}$ & - & - & - & - & - & 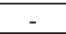 \\
\hline & & $30^{\circ}$ & 2.18 & 2.74 & 3.38 & 12.49 & 14.39 & 16.36 \\
\hline & & $45^{\circ}$ & 1.85 & 2.20 & 2.61 & 12.70 & 15.10 & 17.96 \\
\hline & & $60^{\circ}$ & 1.71 & 1.92 & 2.13 & 13.88 & 16.77 & 19.91 \\
\hline \multirow{16}{*}{ Tension } & & $90^{\circ}$ & - & - & - & - & - & - \\
\hline & \multirow{5}{*}{$\begin{array}{l}\text { Metal } \\
\text { Plates }\end{array}$} & $0^{\circ}$ & - & - & - & - & - & - \\
\hline & & $30^{\circ}$ & 3.88 & 4.80 & 5.83 & 3.69 & 4.32 & 4.97 \\
\hline & & $45^{\circ}$ & 3.38 & 4.02 & 4.79 & 3.63 & 4.32 & 5.13 \\
\hline & & $60^{\circ}$ & 3.20 & 3.62 & 4.06 & 3.82 & 4.54 & 5.31 \\
\hline & & $90^{\circ}$ & - & - & - & - & - & - \\
\hline & \multirow{5}{*}{ Screws } & $0^{\circ}$ &  & - & - & - & - & - \\
\hline & & $30^{\circ}$ & 2.81 & 3.26 & 3.84 & 1.92 & 2.34 & 2.80 \\
\hline & & $45^{\circ}$ & 2.52 & 3.00 & 3.57 & 1.73 & 2.06 & 2.45 \\
\hline & & $60^{\circ}$ & 2.52 & 2.92 & 3.33 & 1.69 & 1.93 & 2.19 \\
\hline & & $90^{\circ}$ & - & - & - & - & - & - \\
\hline & \multirow{5}{*}{ Nails } & $0^{\circ}$ & - & - &  & - & 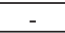 & - \\
\hline & & $30^{\circ}$ & 2.57 & 1.78 & 1.78 & 1.70 & 1.96 & 2.23 \\
\hline & & $45^{\circ}$ & 2.51 & 2.99 & 3.56 & 1.72 & 2.05 & 2.44 \\
\hline & & $60^{\circ}$ & 2.64 & 3.13 & 3.65 & 1.88 & 2.27 & 2.69 \\
\hline & & $90^{\circ}$ & - & - & - & - & - & 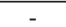 \\
\hline
\end{tabular}

factor is standardized for the different tests performed. However, there are small differences between species, $G$. arborea is slightly higher than $T$. grandis. Likewise, in density there are differences among species (Table I), which is expected, since $G$. arborea is classified as low average density wood and the $T$. grandis as high density wood (Moya and Gonzalez, 20I4). Density is an important indicator of the strength of wood (Shrivastava, 2000; Antwi-Boasiako and Pitman, 2009, Kessels Dadzie et al., 20I5), therefore, it is expected that $T$. grandis had the highest stress values than wood of $G$. arborea. However, the difference in density between species can be compensated by the increase in the dimensions of the structural elements (Keenan and Tejada, 1987; Moya and González, 20I4; Moya and Tenorio 2017).

Types of failures

Different failures were observed according to each fastener (Figure 3). But it is evident that the greatest failure occurs at the edges or sides of each truss connection. For failures in truss connections with metal plates, which agrees with what was stated by Ellegaard (2007) that deformations are mainly due to a slip between the nail of the plate and timber; and/or the nail of the plate will be deformed on the articular line (Figure 3a). On the other hand, in truss connections 
TABLE 4 Stress prediction for the best model by exponential factor, for intermediate angles of truss connections made using various angles and fasteners from Gmelina arborea and Tectona grandis lumbers, tested in compression and tension.

\begin{tabular}{|c|c|c|c|c|c|c|c|c|c|c|c|c|c|}
\hline \multirow[b]{2}{*}{ Species } & \multirow{2}{*}{ Test } & \multicolumn{4}{|c|}{ Metal Plates } & \multicolumn{4}{|c|}{ Screws } & \multicolumn{4}{|c|}{ Nails } \\
\hline & & $\mathrm{n}$ & $\mathrm{R}$ & Angle & $\mathrm{K}$ & $\mathrm{n}$ & $\mathrm{R}$ & Angle & $\mathrm{K}$ & $\mathrm{n}$ & $\mathrm{R}$ & Angle & $\mathrm{K}$ \\
\hline \multirow{6}{*}{$\begin{array}{l}\text { Gmelina } \\
\text { arborea }\end{array}$} & & & & $30^{\circ}$ & 13.90 & \multirow{3}{*}{1.75} & \multirow{3}{*}{0.9994} & $30^{\circ}$ & 2.75 & \multirow{3}{*}{1.75} & \multirow{3}{*}{0.9997} & $30^{\circ}$ & 3.05 \\
\hline & Compression & 1.5 & 0.9998 & $45^{\circ}$ & 12.38 & & & $45^{\circ}$ & 2.21 & & & $45^{\circ}$ & 2.40 \\
\hline & & & & $60^{\circ}$ & 11.69 & & & $60^{\circ}$ & 1.89 & & & $60^{\circ}$ & 2.02 \\
\hline & \multirow{3}{*}{ Tension } & \multirow{3}{*}{1.5} & \multirow{3}{*}{0.9992} & $30^{\circ}$ & 4.80 & \multirow{3}{*}{1.5} & \multirow{3}{*}{0.9998} & $30^{\circ}$ & 3.26 & \multirow{3}{*}{1.0} & \multirow{3}{*}{0.9987} & $30^{\circ}$ & 2.57 \\
\hline & & & & $45^{\circ}$ & 4.02 & & & $45^{\circ}$ & 3.00 & & & $45^{\circ}$ & 2.51 \\
\hline & & & & $60^{\circ}$ & 3.62 & & & $60^{\circ}$ & 2.92 & & & $60^{\circ}$ & 2.64 \\
\hline \multirow{6}{*}{$\begin{array}{l}\text { Tectona } \\
\text { grandis }\end{array}$} & \multirow{3}{*}{ Compression } & \multirow{3}{*}{1.5} & \multirow{3}{*}{0.9998} & $30^{\circ}$ & 16.82 & \multirow{3}{*}{1.75} & \multirow{3}{*}{0.9996} & $30^{\circ}$ & 4.49 & \multirow{3}{*}{1.5} & \multirow{3}{*}{0.9998} & $30^{\circ}$ & 14.39 \\
\hline & & & & $45^{\circ}$ & 15.19 & & & $45^{\circ}$ & 5.48 & & & $45^{\circ}$ & 15.10 \\
\hline & & & & $60^{\circ}$ & $|4.5|$ & & & $60^{\circ}$ & 7.30 & & & $60^{\circ}$ & 16.77 \\
\hline & \multirow{3}{*}{ Tension } & \multirow{3}{*}{1.5} & \multirow{3}{*}{0.9997} & $30^{\circ}$ & 4.32 & & & $30^{\circ}$ & 2.34 & \multirow{3}{*}{1.5} & \multirow{3}{*}{0.9998} & $30^{\circ}$ & 1.96 \\
\hline & & & & $45^{\circ}$ & 4.32 & 1.5 & 0.9998 & $45^{\circ}$ & 2.06 & & & $45^{\circ}$ & 2.05 \\
\hline & & & & $60^{\circ}$ & 4.54 & & & $60^{\circ}$ & 1.93 & & & $60^{\circ}$ & 2.27 \\
\hline
\end{tabular}

with screw, the main failure is due to the separation of the fastener, due to the stress concentration effect in the wood surrounding the screws. In this failure, wood near the screws is not crushed (Figure 3b), but the fastener fails (Song et al. 2015). As for truss connections with nails, these detached what were in the lateral parts of the truss connections (Figure 3c). Sosa et al. (20l4) and Johasen (1949) mention that truss connections with nails and bolt have a ductile failure due to the sliding of nails in the connections.

\section{Load and displacement values}

In the maximum load values of the compression test for both species, is observed that the differences appear in the fasteners; where mainly the metal plates surpass the nails and screws in these resistance values (Figure 3). What indicates that metal plate, presents favorable conditions in the mechanism of truss connections and friction, resulting in greater resistance in compression or tension forces (Seki et al., 20/3). In addition, the values of shear force in truss connections with dented plates vary from 8 to $18 \mathrm{~N}$, these values are close to those reported by Gebremedhin, et al. (1992), which report force values of $14078 \mathrm{~N}$ to $27610 \mathrm{~N}$ in the species Pinus sp.

\section{Load and displacement values}

In the maximum load values of the tension test for both species, for truss connections with $0^{\circ}$ angle, there is not a fastener that protrudes before the others (Figure 3). These differences can be attributed to the pieces of wood that compose the truss connection, making forces to be distributed, regardless the type of fastener (Moya and Tenorio, 2017). In truss connections with a $90^{\circ}$ angle of $G$. arborea timber (Figure 3), there is a marked difference in the superiority of metal plates. Fueyo et al. (2009) based on the study of metal plate truss connections at $45^{\circ}$ angles and modeling as finite elements explain that with the transmission of stresses by contact, the adhesion tensions in metal plates are discharged, reason why adhesion tensions with the plates are somewhat higher. For truss connections of $T$. grandis at $90^{\circ}$, the highest load values are similar to the values in the nails (Figure 3). According to lzzi et al. (2016), suggest that residual stresses could have an influence on the bending of the nails; and therefore, have greater adaptability to be subjected to load, so it could be the explanation for values between nails and plates in the stress tests.

Displacement values, both in the compression tests and the tension tests, report differences between the fasteners, but in this case the fasteners with nails and screws exceed truss connections with metal plates (Figure 4). The greatest force for truss connections with screws, as occurred in the present study with the greatest displacement in truss connections of $G$. arborea in the angle of $0^{\circ}$ for both tests (Figure 4) and the angle $0^{\circ}$ in compression for $T$. grandis (Figure $4 b$ ), is attributed to the greater adherence to wood fibers allowed by the threaded area of the screw, which exerts a greater resistance to extraction during the shear test (Soltis 2010, Moya and Tenorio 2017). On the other hand, the greatest displacement in truss connections with nails, in $G$. arborea in angle of $90^{\circ}$ for both tests (Figure 4a) and for the angle $90^{\circ}$ in compression for $T$. grandis (Figure $4 \mathrm{~b}$ ) can be attributed to the fact that truss connections with nails often subject to lateral forces instead of extraction forces, so lateral forces provide greater resistance to deformation (Takanashi et al. 20I7).

In the behavior of the load with the displacement, the metal plates show again the best behavior, few displacements with the highest load values (Figure 6). Truss connections with metal plates in $G$. arborea for $0^{\circ}$ in compression clearly show this behavior of the load with deformation (Figure 6a). Again, this is explained with the provisions of Gebremedhin et al. (1992) and Johasen (1949) indicating that in the extraction of the tooth there is a wood 
failure. Moreover, in the angle of $0^{\circ}$ the applied forces run parallel to the wooden piece that serves as support in the truss connections, which contributes to support greater loads as it happens in the case of dented plates. While in the compression test for $T$. grandis there was a greater load in truss connections with screws along the entire load- $\Delta$ curve. This can be attributed to the piece of wood that conforms the truss connections, since it allows the forces to be distributed and, therefore, contributes to supporting the loads (Moya and Tenorio 2017).

\section{Design values}

For design values and critical displacement stress, as expected, metal plates surpass the nails and screws in both species; and in the two angles (Table II), this due to the foregoing, since plates have a greater capacity for fastening with wood than nails or screws (Seki et al., 20I3). Moya and Tenorio (2017), also found that lower values in design stress and critical displacement stress, such as the present study, in the tension and compression test, for both species, at $90^{\circ}$ angles. As explained by Gebremedhin et al. (1992) for truss connections in the $90^{\circ}$ angle, the cutting plane was perpendicular to the main axis of the truss connections, placing greater force on the fastener, causing the failure (Gebremedhin et al., 1992). The differences in coefficient of variation depending of external variables, like the distribution of nails/screws in the truss connections or the location of metal plates in center of pieces in the truss connections, as mentioned Gebremedhin et al. (1992), control the manufacture of the truss connections, would minimize variations in MOE, SG, and MC between the connected pieces.

\section{Prediction of stiffness for intermediate}

In the equation for the prediction of critical stiffness (Equation 3), the $\mathrm{n}$ exponent was first determined, which did not present a uniform value in all truss connections types, $\mathrm{n}$ values of $\mathrm{I} .00, \mathrm{I} .50$ and I.75 were found (Table $5)$. In addition to this, models of the exponent $n$ allow the prediction model for intermediate angles to produce a second-degree polynomial equation $\left(y=a * x^{2}+b\right.$ $* x+c)$. Table $V$ shows the models for the prediction of stiffness $\left(K_{\theta}\right)$ for the intermediate angles in the truss connections evaluated for both species ( $G$. arborea and $T$. grandis) and the three types of fasteners (metal plates, screws and nails). For these models, it is possible to derive the stress that will be presented at intermediate angles in wooden structures, based on the results of the research presented here.
The evaluation in experimental test of predictive model was found that truss connections with angles of $30^{\circ}$, $45^{\circ}$ and $60^{\circ}$ fabricated in $G$. arborea wood jointed with nail in compression force, the values in three angles were near to slope line (Figure 7) and the bias was 3\%. There the model development for stiffness for truss connections with different angles presented good prediction.

TABLE 5 Model for prediction of stiffness $\left(K_{\theta}\right)$ for Gmelina arborea and Tectona grandis truss connections of intermediate orientations, between $0^{\circ}$ and $90^{\circ}$ angles and with the two types of fastener.

\begin{tabular}{|c|c|c|c|}
\hline Species & Fastener & Test & $\begin{array}{c}\text { Model for prediction of stiffness for truss } \\
\text { truss connection }\end{array}$ \\
\hline \multirow{6}{*}{$\begin{array}{l}\text { Gmelina } \\
\text { arborea }\end{array}$} & Metal & Compression & $\mathrm{K}_{\theta}=0.0015^{*} \theta^{2}-0.2115^{*} \theta+18.892$ \\
\hline & Plates & Tension & $\mathrm{K}_{\mathrm{\theta}}=0.0007 * \theta^{2}-0.1082 \theta^{*}+7.4506$ \\
\hline & \multirow{2}{*}{ Screws } & Compression & $\mathrm{K}_{\mathrm{\theta}}=0.0003 * \theta^{2}-0.0573 \theta^{*}+4.1297$ \\
\hline & & Tension & $\mathrm{K}_{\theta}=0.0003 * \theta^{2}-0.0393 \theta^{*}+4.1503$ \\
\hline & \multirow{2}{*}{ Nails } & Compression & $\mathrm{K}_{\theta}=0.0004 * \theta^{2}-0.0715 \theta^{*}+4.7768$ \\
\hline & & Tension & $\mathrm{K}_{\theta}=0.0005 * \theta^{2}-0.0437 \theta^{*}+3.3960$ \\
\hline \multirow{6}{*}{$\begin{array}{l}\text { Tectona } \\
\text { grandis }\end{array}$} & Metal & Compression & $\mathrm{K}_{\theta}=0.0017^{*} \theta^{2}-0.2335 \theta^{*}+22.266$ \\
\hline & Plates & Tension & $\mathrm{K}_{\theta}=0.0004 * \theta^{2}-0.0292 \theta^{*}+4.8207$ \\
\hline & \multirow{2}{*}{ Screws } & Compression & $\mathrm{K}_{\theta}=0.0014 * \theta 2-0.0263 \theta * 3.9277$ \\
\hline & & Tension & $\mathrm{K}_{\theta}=0.0003 * \theta^{2}-0.0382 \theta^{*}+3.2478$ \\
\hline & \multirow{2}{*}{ Nails } & Compression & $\mathrm{K}_{\theta}=0.0170 * \theta 2-0.0754 \theta^{*}+15.032$ \\
\hline & & Tension & $\mathrm{K}_{\mathrm{\theta}}=0.0002 * \theta 2-0.0104 \theta^{*}+2.06 \mathrm{I} 4$ \\
\hline
\end{tabular}

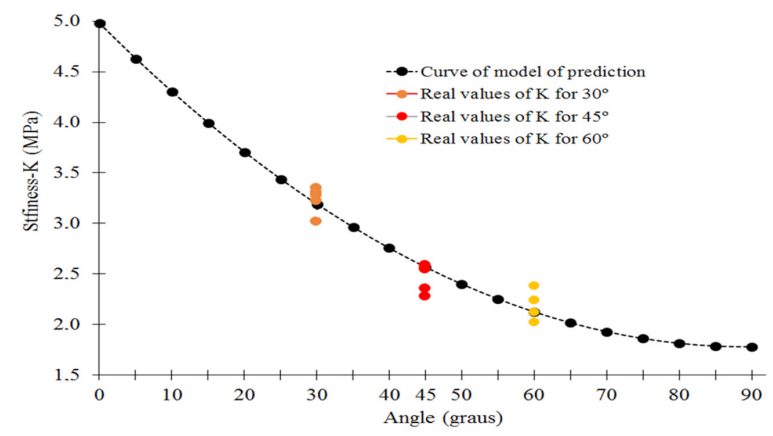

FIGURE 7 Curve development from prediction model of stiffness $(\mathrm{K} \theta)$ for Gmelina arborea in compression test and real test for angle of $30^{\circ}, 45^{\circ}$ and $60^{\circ}$.

The results obtained in the present study are innovative since it is the first time they are presented, although this topic is a widely known in countries with great development of wood constructions, but in developing countries (located many of them in tropical regions) are little known and especially derived from species, such as $G$. arborea and $T$. grandis, used in reforestation programs and also important in international markets. So, these results will be the basis to continue with the development of markets for these species in the area of civil construction.

\section{CONCLUSIONS}

In the results of maximum load in compression, the superiority statistic of metal plates over the other two 
fasteners is evident. The behavior of the fasteners in load vs. displacement shows that metal plates in $G$. arborea for $0^{\circ}$ in compression test showed higher loads, while in tension tests in both species the $90^{\circ}$ angle in metal plates is the presented too higher loads. Statistical analysis also gives as results that values in design stress and critical displacement stress are greater in metal plates for both species; and in the two angles.

From the stresses in the compression and tension tests, for angles of $0^{\circ}$ and $90^{\circ}$ for the species $G$. arborea and $T$. grandis, and the use of fasteners: metal plates, screws and nails, can be predicted using the following models: and the bias can be lower than $3 \%$.

\section{ACKNOWLEDGEMENTS}

The authors are grateful for the support of the Vicerrectoría de Investigación y Extensión of the Instituto Tecnológico de Costa Rica and also to Aserraderos S\&Q S.A. and Novel Teak, who contributed the materials for truss connections.

\section{REFERENCES}

ANTWI-BOASIAKO C, ATTA-OBENG E. Vessel-fibre ratio, specific gravity anddurability of four Ghanaian hardwoods. Journal of Science Technology, v.29, n.3, p.8-23, 2009.

ASTM DI76I- 06., 20I2. Standard test method for mechanical fasteners in wood. ASTM International, West Conshohocken, PA. Available in: www.astm.org. Accessed in: 12 November 2017.

BARBARI, M., CAVALLI, A., FIORINESCHI, L., MONTI, M., TOGNI, M. Innovative connection in wooden trusses. Construction and Building Materials, v.66, p.654-663, 2014.

CWC (CANADIAN WOOD COUNCIL). Resilient and adaptive design using wood. (I). Available from: http:// cwc.ca/wp-content/uploads/2017/02/Resilience-FactSheet-February-8-2017.pdf. Accessed in: 03 November $2017,2017 a$.

CWC (CANADIAN WOOD COUNCIL). Moisture and wood-frame buildings. International Building. (I), I-20. Available from:http://cwc.ca/wp-content/uploads/ publications-IBSI_Moisture_SMC_v2.pdf. Accessed in: 03 November $2017,2017 \mathrm{~b}$.

DVORAK, W. S. World view of Gmelina arborea: opportunities and challenges. New Forests, v.28, n.2, p. I I I-I26, 2004.

ELLEGAARD, P. Effect of chord splice joints on force distribution and deformations in trusses with punched metal plate fasteners. Holz als Roh- und Werkstoff, v.65, p.469-475, 2007.
FUEYO, J., CABEZAS, J.A., DOMINGUEZ M., RUBIO, M.P. Análisis de tensiones en uniones de tres barras de cerchas ligeras de madera realizadas con placas-clavo. Información Tecnológica, v.20, n.6, p.45-56, 2009.

GEBREMEDHIN, K. G., JORGENSEN, M. C., WOELFEL, C. B. Load-slip characteristics of metal plate connected wood joints tested in tension and shear. Wood Fiber and Science, v.24, n.2, p.II8-132, 1992.

GREEN, M. KARSH, J.E. The case for tall wood buildings how mass timber offers a safe, economical, and environmental friendly alternative for tall building structures. Wood Enterprise Coalition, FP Innovations, FII, BC WoodWorks, the Canada Wood Council and BC Wood. Ottawa, Ca, 20I2, 240 p.

HEI, M.J., ZHANG, J., LI, Z., LI, M.L. Production and mechanical performance of scrimber composite manufactured from poplar wood for structural applications. Journal of Wood Science, v.62, p.429-440, 2016.

INEC (INSTITUTO NACIONAL DE ESTADÍSTICA Y CENSOS). VI Censo Nacional Agropecuario 20I4. San José: INEC, 2014.

IZZI, M., FLATSCHER, G., FRAGIACOMO, M., SCHICKHOFER, $G$. Experimental investigations and design provisions of steelto-timber joints with annular-ringed shank nails for CrossLaminated Timber structures. Construction Building and Material, v. I22, p.446-457, 2016.

JOHANSEN, K. W. Theory of timber connections. International Association Bridge and Structural Engineering, v.9, p.249-262, 1949.

KEENAN, F. J., TEJADA, M. Maderas tropicales como material de construcción en los países del grupo andino de América del Sur. Centro Internacional de Investigación para el Desarrollo. Ottawa, CA, pp. 69-89, 1987.

KEOGH, R.M. La teca y su importancia económica a nivel mundial. Las plantaciones de teca en América Latina: mitos y realidades. Centro Agronómico Tropical de Investigación y Enseñanza (CATIE). Serie Técnica. Boletín Técnico, v.397, p.8-28, 2013

KESSESLS DADZIE, P., AMOAH, M., BOAMPONG, E., FRIMPONG-MENSAH, K. Effect of density and moisture content on biological durability of stem and branch wood of Entandrophragma cylindricum (sapele). Journal of Indian Academy of Wood Science, v. I2, n. I, 44-53, 2015.

MCCARTHY, M., LITTLE, J. Sensitivity of truss plate model parameters to parameter determination methods. Forests Products Journal, v.38, n.5, p.63-67, 1988.

MOYA, R., GONZÁLEZ, G. Esfuerzos admisibles de diseño por grado estructural para nueve maderas de plantación de Costa Rica. Revista Forestal Mesoamericana, v. I I, n.26, p. I-I2, 2014 
MOYA, R., BOND, B., QUESADA-PINEDA, H. A review of heartwood properties of Tectona grandis trees from fastgrowth plantations. Wood Science Technology, v.48, n.2, p.4| I-433, 2014.

MOYA, R., TENORIO, C., CARRANZA, M., CAMACHO, D., QUESADA-PINEDA, H. Structural performance of I-beam fabricated of $G$ melina arborea from fast growing trees. Journal Tropical Forest Science, v.25, n.2, p.206-212, 2013.

MOYA, R., TENORIO, C. Strength and displacement under tension and compression of wood joints fastened with nails and screws for use in trusses in Costa Rica. Wood Research, v.62, n.I, p.I39-I56, 2017.

PREVATT, D. O., SHREYANS, S., KERR, A., GURLEY, K. R. In situ nail withdrawal strengths in wood roof structures. Journal Structural and Engineering, v.l40, n.5, p.040I4008, 2014.

RAMMER, R. D. Wood: mechanical fasteners. In: Saleem Hashmi (editor-in-chief), Reference Module in Materials Science and Materials Engineering, I-10, 2016.

SAWATA, K., SHIGEMOTO. Y., HIRAI, T., KOIZUMI, A., SASAKI, Y. Shear resistance and failure modes of nailed joints loaded perpendicular to the grain. Journal of Wood Science, v.59, p.255-26I, 2013.

SBCA (STRUCTURAL BUILDING COMPONENTS ASSOCIATION) and TPI (TRUSS PLATE INSTITUTE). Guide to good practice for handling, installing, restraining and bracing of metal plate connected wood trusses. Available from: http://support.sbcindustry.com/docs/06 BCSI_booklet_FINAL.pdf. Accessed in: 03 November 2017, 2013.

SEKI, M., SUGIMOTO, H. MIKI, T., KANAYAMA, K., FURUTA, Y. Wood friction characteristics during exposure to high pressure: influence of wood/metal tool surface finishing conditions. Journal of Wood Science, v.59, p. 10-16, 2013.

SERRANO, R., MOYA, R. Procesamiento, uso y mercado de la madera en Costa Rica: aspectos históricos y análisis crítico. Revista Forestal Mesoamericana, v.8, n.2 I, p. I- I2, 201 I
SHRIVASTAVA, MB. Wood technology. Vikas Publishing House Pvt. Ltd., New Delhi, 2000.

SOSA, M.A., KÖHLER, J., PITER, J.C. Load-carrying capacity of timber-to-timber joints of fast-growing Argentinean Eucalyptus grandis with nails of small diameter laterally loaded in double shear: analysis according to the criterion adopted by European standards. European Journal of Wood Products, v.72, p.2I-3I, 2014.

SOLTIS, L.A. Fastenings, Chapter 8. Wood handbook: Wood as an engineering material. Forest Products Laboratory. General Technical Report GTR-II3. Madison, Wisconsin, EE UU, I-29, 1999.

SONG, X., WU, Y., JIANG, R. Compressive capacity of longitudinally cracked wood columns retrofitted by selftapping screws. Journal of Zhejiang University-Science A Applied Physics \& Engineering, v. 16, n. I2, p.964-975, 2015

TAKANASHI, R., SAWATA, K., SASAKI, Y., KOIZUMI, A. Withdrawal strength of nailed joints with decay degradation of wood and nail corrosion. Journal of Wood Science, v. 63 , p. 192-198, 2017.

TENORIO, C., MOYA, R., SAENZ, M., NAVARRO, A., CARRANZA, M., PANIAGUA, V. Diseño, resistencia, tablas de diseño, propuesta de empaque y manuales de uso de cerchas construidas con madera de Gmelina arborea e Hieronyma alchorneoides de plantaciones forestales en Costa Rica. Revista Forestal Mesoamericana, v. 14, n.35, p. 55-67, 2017.

ZHANG, J., XU, Q., XU, Y., ZHANG, M. Research on residual bending capacities of used wood members based on the correlation between non-destructive testing results and the mechanical properties of wood. Journal of Zhejiang University-Science A Applied Physics \& Engineering, v. I6, n.7, p.54I-550, 2015

ZHANG, Y., THOMPSON, D., SQUICCIARINI, G., RYUE, J., $X I A O, X$., WEN, Z. Sound transmission loss properties of truss core extruded panels. Applied Acoustic, v. I3I, p.|34-153, 2018. 